\title{
Matrimonial Relations in Shakespeare's The Taming of the Shrew: The Machiavellian Husband/Ruler
}

\author{
Khaled M. Shuqair ${ }^{1}$ \\ ${ }^{1}$ Department of English, College of Basic Education, The Public Authority for Applied Education and Training, \\ Kuwait \\ Correspondence: Khaled M. Shuqair, Department of English, College of Basic Education, The Public Authority \\ for Applied Education and Training, Kuwait. Tel: 965-9402-6999. E-mail:kmshuqair@gmail.com
}

Received: April 12, 2014 Accepted: May 29, 2014 Online Published: August 29, 2014

doi:10.5539/ells.v4n3p18 URL: http://dx.doi.org/10.5539/ells.v4n3p18

\begin{abstract}
This paper explores the matrimonial relations in Shakespeare's The Taming of the Shrew in terms of the Machiavellian views on the rule-subject relationship. It argues that the play presents a paradigm of power whereby the husband/ruler acts in a Machiavellian manner to subordinate the wife/subject through fear first, and then love. Like a Machiavellian ruler, Petruchio, the husband, coerces Katherine into obedience and order. His coercion is looked as a necessary evil to achieve the higher goal of order. Such a paradigm manifests itself in the little world of the family but is also symbolic of larger issues of social order in early modern England.
\end{abstract}

Keywords: gender, love, Machiavelli, matrimonial relations, power, The Taming of the Shrew

Kath. I am asham'd that women are so simple

To offer war where they should kneel for peace,

Or seek for rule, supremacy, and sway,

When they are bound to serve, love, and obey

(5. 2. 161-64).

A central theme of The Prince is Machiavelli's new take on the classic opposition of fortune and virtue. In late medieval philosophy, Christian virtue could defeat the goddess Fortune by making a man indifferent to her blows. Machiavelli, however, argues that although a private individual could afford to hold the world in contempt, a prince has to aggressively impose his own will upon it. He inverts the standard virtue-fortune model, stating that a man with sufficient virtu' can violently conquer Fortuna. According to Machiavelli, like the goddess, the state belongs to the man who wins her by force:

I am certainly convinced of this: that it is better to be impetuous than cautious, because fortune is a woman, and it is necessary, in order to keep her down, to beat her and to struggle with her. And it is seen that she more often allows herself to be taken over by men who are impetuous than by those who make cold advances; and then, being awoman, she is always the friend of young men, for they are lesscautious, more aggressive, and command her with more audacity. (84; ch.25) (Note 1)

Here, Machiavelli clearly draws a parallel between the energy required for a violent sexual encounter and that which determines the drive for political power. Machiavelli's analogy is based on the underlying assumption that the male's relationship to the female is that of coercion and subjection. Therefore, as much as this passage speaks of the Machiavellian statesman, it also comments on the male who, according to Machiavellian rules, could win his female only through force. In the following discussion, I would like to argue that Shakespeare's The Taming of the Shrew seems to propose that the ideal husband is one who would act as a Machiavellian prince to subjugate the wife and establish peace and order.

Machiavelli's work shocked sixteenth century audiences, particularly the English who were appalled by Machiavelli's ideas; hence the enormous popularity in the late sixteenth century of the villainous "stage Machiavel." By the beginning of the seventeenth century in England, however, the real Machiavelli started to 
replace the "Machiavel," opening the way for both the republicanism of The Discourses and the "regione di stato" of The Prince (Note 2). Thus the "Machiavel"- the villainous character-was replaced on the Renaissance stage by the Machiavellian - the pragmatist and man of virtu'. In the same chapter that contains the famous statement that fortune is a woman, Machiavelli praises the man of virtu', that rare man who is able to change his nature with the times. In the most general terms Machivellianvirtu' is the talent to act in whatever way will bring success, and it is, therefore, closely allied to prudence (Note 3 ).

An analysis of the portrait of marriage in Shrew suggests that the play promotes a model of husband, reflecting standards of conduct that are Machiavellian. Petruchio has the machiavellianvirtu' as a husband/ruler in that, in the marital world which is governed by contingency, he is able to change his nature with the times. According to Machiavelli, a prince's main concern is to bring peace, order and obedience to his state, mostly through fear and cruelty. Likewise, the play seems to say that a husband establishes domestic order and obedience through coercion and fear. As such, there emerges a basic analogy through which to read the marriage structure in the play: a Machiavellian ruler is to his subordinates as a husband is to his wife. A man with virtu', Petruchio is the ruler/husband who makes a perfect Machiavellian.

The two sides of Petruchio's personality — one attractive, the other repulsive - have oriented criticism of the play. Critics who focused on the attractive side have been able to find in the play Shakespeare's mirror of ideal marriage, where the couples, Katherine and Petruchio, reach mutual understanding based on love and respect. Marianne Novy views the idea of taming as a game played by both Katherine and Petruchio in order to reconcile Katherine to her society. The game context permits Petruchio and Katherine to change from antagonists to co-creators of a new world, and encourages the spectators to see the play as "only a game." Thus Katherine's final speech is, according to Novy, an "affectionate contract" of marriage, "a relationship in which both partners have a role to play" (380). Jeanne Roberts points out that the play depicts "two flawed lovers in quest of an ideal union" (161), and as such Petruchio is equally tamed at the end (171). Richard Burt argues that Petruchio's taming is just a "strategy" in the service of domestic and social unity, and he abandons it in the final moments of the play because it is no longer necessary. He concludes that the love between Petruchio and Katherine is "entirely separate from coercion" and that Katherine has been waiting for someone like Petruchio to come along and tame her (304). Camille Slights argues that Shakespeare is less interested in suggesting the proper distribution of power between men and women than in exploring the comedy inherent in the human desire for both individual freedom and fulfillment as a social being. Thus the play hinges on a contrast not between men and women but between "civilized and uncivilized behavior"(169); Katherine is uncivilized because she acts in terms of unexamined social conventions (179). According to Joan Hartwig, the transformation of Katherine is metaphorized as a horse to be curbed; however, this curbing is one "from unhappy shrew to graceful woman." Marion Perret focuses on Petruchio as a shrew tamer who attempts to school the shrew by assuming her responsibilities, teaching her through his own example just how a wife should behave. Margaret Renald argues that the battle in the play is fought on a psychosexual level and that it is not merely a matter of a supremacist psychic murder, but rather a combat of two fiercely independent and sexually attracted persons. Thus the play productions with Petruchio as a violent man are not justified. Elizabeth Hutcheon views Petruchio as a humanist educator and contends that the success of his humanist methodologies in the domestic sphere not only highlights their effectiveness as a mode of discipline and education, but also reveals humanism's fundamental lack of gendered priorities. That is to say, if Petruchio makes Katherine subject to his will, she is so as the citizen is subject to the monarch, not as women are subject to men.

On the other hand, most feminist criticism tends to highlight Petruchio's repulsiveness and Katherine's dehumanization through male's coercion and subjugation. Such a critique hinges on the idea that an historicized confrontation with the play would reveal woman's spectacularization and subjugation as costs exacted for her resistance in the social order of early modern England. One important work that has forever altered perceptions of Katherine's taming is Lynda Boose's "Scolding Brides and Bridling Scolds: Taming the Woman's Unruly Member." Documenting early modern punishments of scolds, their cucking and bridling, in excruciating details, Boose argues that the play is a romanticized version of the woman's subjection, which is a reflection of "an obsessive energy" invested to exert control over the unruly woman in early modern England, and, hence, Katherine's suffering is anything but trivial, deserved, or therapeutic (195). Somewhere else she also argues that the issues of gender and hierarchy in the play are pushed outside the story of Petruchio and Katherine in order to be examined among "a variety of historicized construction sites," which include the material conditions of early modern England (The Taming of the Shrew, p. 194). In "Katherine of The Taming of the Shrew: 'A Second Grissel," Carolyn E. Brown comes very close to giving Katherine's character a tragic status. Brown makes a powerful argument for removing Katherine from classic and simplistic shrew literature; instead Brown places 
her among literature's long-suffering Griseldas. She also notes Petruchio's resemblance to the Griselda figure's frightening tormentor. Focusing on the relationship of gender to subjectivity and how Shakespeare's theater staged female's obedience for the visual pleasure of its male auditors, Maureen Quilligan could argue that Katherine's final speech shows the function of pure power in gender determinations. In "The Taming of the Shrew: Inside or Outside the Joke," Shirly Nelson Garner separates the experience of female-versus male-identified viewers as they witness the treatment of Katherine, arguing that the play is a comedy only for the latter group (Note 4). Victoria Moreno argues that both Katherine and Bianca represent the warring aspects of the feminine psyche which suffers from a rupture symbolized by Kate's rage and her reaction to cultural values that demand the repression of the feminine expression, on the one hand, and Bianca's complacency and unquestioning obedience to these values, on the other.

I would like to argue with the feminist scholars that the play is essentially a romanticized version of male's dominance over woman, which reveals a historical context where gender crisis was salient. However, I would like to propose that the play presents the idea of marriage in such a way that the relation of the wife - the potentially disorderly woman - to her husband becomes an epitome for the relation of subordinates to their ruler. In the little world of the family, with its conspicuous tension between love and power, the larger matters of political and social order could find ready symbolization. In this world, the powerful Pertruchio acts in a Machiavellian manner to subjugate the powerless Katherine. His brutality is justified as a necessary evil in order to achieve social order as a higher moral goal. Love is contingent on the establishment of male's power in such a matrimonial relation; the husband is feared first, and then loved. Similarly, according to Machiavellian standards a successful ruler should build his state on fear rather than love for, while love is precarious, fear is held by a dread of punishment. Thus the marriage of Petruchio and Katherine is praised and rewarded at the end, because such a matrimonial relationship exorcised the fear of disorder that dominated early modern England.

The language of the play seems to suggest that the household is the microcosm of the state, and women's subjection in marriage a happy paradigm of civil order. Rule and supremacy are the privilege of the husband, while the wife is bound to serve and obey. As the epigraph of this paper shows, Katherine's speech contains a conflation of civic and domestic terminology, and hence the reader is invited to see the woman's subjugation in marriage as a paradigm for social order. Shakespeare's conflation of the civic and the domestic can also be seen in other plays. The most interesting examples in the light of this study are references to the sovereignty women may have, or at least desire, within the domestic sphere. For instance, in Love's Labour's Lost, Boyet states to the Princess:

Do not curst wives hold that self-sovereignty

Only for praise's sake, when they strive to be

Lord o'er their lords? (4.1.36-38)

To which the Princess replies: "Only for praise - and praise we may afford/To any lady that subdues a lord" (4.1.39-40). Obviously, this is a light exchange; nevertheless, the terminology of power within the domestic sphere is clearly drawn. In another example from one of Shakespeare's early comedies, the context is one of coercion like that of Shrew. When in A Midsummer Night's DreamHermia is commanded by Theseus to obey her father and marry Demetrius, he states that her father should be to her "as a god" (1.1.47). Then the Duke asks Hermia to choose among three harsh fates: she may obey her father and marry a man she despises; she may willingly die; or she may live the rest of her life a nun. Theseus tries to shape her decision by describing cloistered life as a kind of living death, but Hermia replies that given these alternatives she will choose to become a nun:

So will I grow, so live, so die, my lord,

Ere I will yield my virgin patent up

Unto his lordship, whose unwished yoke

My soul consents not to give sovereignty (1.1.79-82).

These bold words by Hermia are filled with political resonances. Her resistant discourse mirrors political consent theory, where it is argued that the governed must freely give their consent to wear the yoke of the governor.

Early modern England was a gender-threatened culture. Fears of an impending breakdown of the social order were widespread and intense. David Uderdown has convincingly argued that England between the years 1560 and 1660 was going through an economic and social transformation that threatened the civil order. Among the causes of that instability were the problems of excessive population growth, inflation, land shortage, poverty, 
vagabondage and the decline in social harmony that accompanied the spread of capitalism. Thus it was no longer safe to assume that all Englishmen and women were bound together in a network of households and communities on which stability depended. At the time, even the patriarchal family, the cornerstone of the whole structure of order, seemed to be threatened; patriarchy could no longer be taken for granted (16-17). Patriarchal authority within the family was the cornerstone of Elizabethan and Jacobean political theory, the ultimate justification for obedience to the state. To reject either of them was to threaten the entire social and political order. Thus with the social and economic transformation of the era there emerged the feeling of anxiety about patriarchal order. As Underdown points out, the subjection of women to patriarchal authority became dominant as a by-product of such a transformation. One manifestation of this public anxiety was "the scold"-a woman disturbing "the peace by publicly abusing family members or neighbors"- who was publicly punished in order to set an example for her fellow women. Before the sixteenth century, the authorities were not particularly concerned about the scolds. And the customary punishments were small fines or penance. However, from the 1560s, many places in England started to show increasing concern about them. For instance, Anne Weeks was presented in a country parish in 1620 as a common scold. Scolding at the time became overwhelmingly female offence (19) (Note 5). As such in that era of civil disorder, the scold became a category of community life. Such criminal categories as "scold" and "brawler" entailed "the reinforcement of hierarchy through difference." At the same time, the cucking- stool as a mechanism for punishment was turned into a carnival experience that spectacularized the woman's body (Boose "Scolding Brides" 189-90).

Lynda Boose also observes that in early modern England the geographic, economic, demographic, and social landscape drastically changed as the pattern of land use and the way of life it had signified were transformed from men working and living on land into a system of private ownership for the few and vagabondage for the many. The change was to a landscape of exclusive ownership. It was during that period that the communities began to impose harsh enclosures against women. At the same time, female "disorder" and "unruliness" came to be seen as a major threat to the integrity of the community ("The Taming of the Shrew" 197-202). It is appropriate to perceive Shrew within this historical context, which reveals the patriarchal authority within the family as a paradigm for obedience to the ruler.

From the outset of the play, Baptista's house is presented as an image of disorder. Katherine's threat to patriarchal authority is perceived by others as shrewishness and witchcraft through the constant allusion to her as "Katherine the curst" (1. 2. 129) (Note 6), and as a woman with a "scolding tongue"(1.2. 100). As Newman observes, the relationship between silence and women's place in "the marriage market" is made clear (93). In an exchange between Katherine and Bianca, we are given two pictures of a "brawling" woman and a "silent" one:

Kath. A pretty peat; it is best

Put finger in the eye, and she knew why.

Bian. Sister, content you in my discontent.

Sir, to your pleasure humbly I subscribe

My books and instruments shall be my company,

On them to look and practice by myself.

And later when Katherine questions Bianca about her suitors, inquiring as to her preferences, she makes clear the relationship between Bianca's silence and her success with men: "Her silence flouts me, and I'll be reveng'd" (2. 1. 28). Even before she is handed over to Petruchio, Katherine is isolated and despised. Her first lines in the play refer to her public humiliation, asking her father if it is his intention to "make a stale [a laughingstock as well as a woman who might be carted as a scold] of me amongst these mates" (91. 1. 58), to which Hortensio, one of her sister's suitors, replies: "'Mates,' maid? How mean you that? No mates for you,/Unless you were of a gentler, milder mold" (1.1.59). A short while later, with the active support of Katherine's family and Paduan society, Petruchio will be granted prerogative of a domestic "free monarch' - the ruler's complete freedom equates to the subject's virtual slavery.

The patriarchal power, manifested in the father figure, is depicted as failure. Katherine's revolt against patriarchal authority is seen as the main cause for the disorder at Baptista's house. Bianca, however, is, as it turns out at the end of the play, a potential shrew. The play deliberately leaves us in the dark as to Bianca's potential shrewishness to drive an important point home: that all women are basically shrews and should be subjugated. At this moment of the play, both Katherine and Bianca enter into the social role of wife. However, while the one is "carted," (coerced and subjugated) the other is "courted" (wooed and wedded).

In chapter 17 of The Prince, Machiavelli warns against depending on the love of one's followers: 
I reply that one should like to be both one and the other; but since it is difficult to join them together, it is much safer to be feared than to be loved when one of the two must be lacking (56),

and Machiavelli explains:

because love is held together by a chain of obligation which, since men are wretched creatures, is broken on every occasion in which their own interests are concerned; but fear is sustained by a dread of punishment which will never abandon you (53).

According to these Machiavellian standards, the husbands-ruler Petruchio proves to be ideal. His strategy is to assert his power through fear and dread of punishment. And we are required to judge, according to the play's terms, which of the two strategies will eventually bring about a successful marriage cherishing the patriarchal authority: Is it power (carting) or love (courting)? Or, in terms of the state metaphor and Machiavellian standards, is the state's wellbeing achieved through the prince's reliance on love or fear?

Machiavelli states that the ideal prince should possess the character of the fox; however, "it is necessary to be able to disguise this character well, and to be a greater feigner and dissembler" (98; ch.18) (Note 7). Likewise, Petruchio proves to be a great dissembler as he deals with Katherine. He masks his tyranny under the cover of gentility. When he first hears about Katherine's "shrewishness," he shows the tyrant inside him:

I am as peremptory as she proud-minded,

And where two raging fires meet together

They do consume the thing that feeds their fury.

Though little fire grows great with little wind,

Yet extreme gusts will blow out fire and all.

So I to her, and she yields to me,

For I am rough and woo not like a babe. (2. 1. 131-137)

However, when he meets her, he puts on the disguise of a loving and caring gentleman:

No, not a whit, I find you passing gentle:

'Twas told me you were rough and coy and sullen,

And I find report a very liar;

For thou art pleasant, gamesome, passing courteous,

But slow in speech, yet sweet as spring-time flowers. (2. 1. 242-246).

Of course, Petruchio does not mean what he says; rather for him the end justifies the means, and he is ready at this point to humble himself to her in order to win her affection. Even when she strikes him, he threatens to "cuff" her if she strikes again (2. 1. 220), but he never does. Some critics, like Margaret Renald, interpret this scene as one that reveals Petruchio's gentility and love at first sight (81). However, Petruchio's conduct here, like that of a Machiavellian prince, seems to be solely governed by necessity; he cloaks his cruelty under gentlemanly conduct.

In the wedding scene, Petruchio coerces his Fortuna, and we witness the process of taming her into submission as an inferior in the marital relation, for Katherine from this point on goes through a process of spectacularization and shaming. At the same time, Petruchio's politic "reign" begins, as he "kills [Katherine] in her own humor," training her as if she were a beast, and all the while pretending that he does it in "reverend care" of her: "This is the way to kill a wife with kindness" (4. 2. 211).

Petruchio's delayed arrival to the wedding is intended to publicly spectacularize Katherine. She rightly insists that Petruchio has shamed her:

Hiding his bitter jests in blunt behavior;

And to be noted for a merry man,

He'11 woo a thousand, 'point the day of marriage,

Make friends, invite, and proclaim the banes,

Yet never means to wed where he hath woo'd. (3. 2. 13-17).

Furthermore, Petruchio's grotesque clothes, as Boose points out, rob Katherine of "the visual centrality that custom invests in bridessynechdochically in the bridal gown" ("Scolding Brides" 192). Like a Machiavellian 
prince, Petruchio is establishing his reign through power and fear not love. When her attempted resistance moves from the verbal to the non-verbal, Petruchio makes his absolute power over her crudely explicit:

Nay, look not big, nor stamp, nor stare, nor fret,

I will be master of what is mine own.

She is my good, my chattels, she is my house,

My household stuff, my field, my barn,

My horse, my ox, my ass, my any thing;

And here she stands, touch her whoever dare. (3. 2. 228-233)

In this passage Petruchio seems to be a character with the boldness and impetuosity that Machiavelli deems essential to conquer the goddess Fortune who is best won by force.

In Act IV, Petruchio's power is further established through Katherine's loss of identity and her subjective vision of the world. Starving her into submission and denying her sleep, Petruchio effects complete mastery over her. All of this violence is done, as Petruchio himself says, "in reverend care of her"(4. 1. 204), and, as Katherine recognizes, "under the name of perfect love" (4. 3.12). It goes without saying that perpetrators of domestic violence will frequently represent their abuse to the victim as being "for their own good," a claim that enforces complicity while degrading any independent sense of self. Beating his servants in front of her, Petruchio conveys to her the message that if she does not prove herself an obedient wife, she will face the same lot as the servants. And depriving her of proper clothing, he drives the point home that he is economically in charge, and that she has to win her bread by submitting her will to his power.

In Petruchio's "taming school," the plot of depriving Katherine of food, sleep, and clothing is less destructive than the device of depriving her of her vision. Whereas the first device leaves Katherine room to react and retain her resistance,

Why, sir, I trust I may have leave to speak,

And speak I will. I am no child, no babe;

Your betters have endur'd me say my mind,

And if you cannot, best you stop your ears.

My tongue will tell the anger of my heart,

Or else my heart concealing it will break,

And than it shall, I will be free,

Even to the uttermost, as I please, in words. (4. 3. 74-80),

the second strategy leaves the stage and the action entirely to Petruchio. By the time the couple is on the way back to Padua, Katherine is no longer defiant. By this point she is willing to swear that the sun is the moon or not the moon as her husband desires. In other words, Katherine now sees the world according to the vision he allows her:

Then, God be blessed, it is the blessed sun.

But sun it is not, when you say it is not,

And the moon changes even as your mind.

What you will have it named, even that it is,

And so it shall be so for Katherine. (4. 5. 18-22).

Petruchio's sovereignty is complete, his powers verging on the ontological. Katherine's will has been more than harnessed; it has been obliterated.

In Chapter 17 of The Prince, Machiavelli argues that a ruler cannot retain all the praiseworthy good qualities. Though he should avoid the scandal of those vices which will lose him the state, "he must not mind incurring the scandal of those vices, without which it would be difficult to save the state," for what appears to be virtues would, if followed, lead to one's ruin, and what appears to be vices might bring about one's good (92). By these Machiavellian standards, Petruchio's "vices" are seen, at least from the perspective of an audience in the sixteenth-century society as the evil that brings good to the society. In a gender-threatened culture, as we have seen, the vice of cruelly subjecting the wife's will, at the very best, be looked at as the scandal incurred to 
establish peace and order; and the comic form of this violence will be cathartic to such a culture.

In The Prince, Machiavelli further warns the statesman against depending on the loyalty of his subordinates because they are "fickle" and not trustworthy. They are controlled by appetite, greed and disorder, and they will revolt as soon as they get the chance. He urges the prince to build his kingdom on fear rather than love since love is "held by a chain of obligation, which, because men are wicked, is broken at every opportunity for their own utility, but fear is held by a dread of punishment that never forsakes you" (97). In Shrew the imagery of the horse and falcon from which the whole play evolves stresses this Machiavellian husband-wife/ruler-subjects relation. Both images imply that the wife cannot be trusted because she is emblematic of disorder and has irrepressible appetites. As Hartwig has shown, Petruchio's treatment of Katherine in his house and on the way back to Padua "resembles the kind of exactitude and repetition of exercises that a rider requires when training his horse in the manage" (288); the underlying assumption is that the horse is the appetite and passion and the rider is the mind or reason holding the body under control (292). Likewise, the image of the falcon implies the same idea of mistrust in the wife. Petruchio describes his relationship with Katherine in terms of falconer and falcon:

My falcon is now sharp and passing empty,

And till she stoop, she must not be full-gorg'd

For then she never looks upon her lure.

Another way I have to man my haggard,

To make her come and know her keeper's call,

That is, to watch her, as we watch these kites

That bate and beat and will not be obedient. (4. 2. 190-196).

The lines indicate that the falcon must be taught obedience to her master, as she is wild and instinctive. She must be taught to exercise her wild nature under the government of her master lest she might revolt.

Harriet Deer has made the penetrating observation that in the play there is a conflation of courtly and folk tastes. While the Petruchio-Katherine plot springs from folk tradition, the Lucentio-Bianca from courtly love tradition (66-67) (Note 8). The Petruchio-Katherine story stresses violence and shrewishness; the Lucentio-Bianca story disguise, music, poetry and love at first sight. At a deeper level, this contrast reveals the difference between a practical and down-to-earth realistic husband, and an impractical and idealistic one. Along with the carting of Katherine, we witness the courting of Bianca. Contrary to the Petruchio-Katherine relationship, that of Lucentio and Bianca is based on love, not power. Within the context of courtly love tradition, Lucentio treats Bianca like a medieval knight. When he first sees her, he says to Tranio: "Tranio, I burn, I pine, Tranio/If I achieve not this young modest girl" (1. 1. 155-156). And, later, he talks about his love to Bianca as a miracle:

Love wrought these miracles. Bianca's love

Made me exchange my state with Tranio

And happily have I arrived at the last

Unto the wished haven of my bliss (5.2. .124-125,127-128).

And at the end they marry happily. There is no sign of coercion, no use of power. Lucentio, unlike Petruchio, is gentle with his servant, Tranio, and treats him as if he is his equal. His little world is built on love, and he assumes that he will derive his patriarchal power from this love. However, Lucentio is significantly left at the end on the sidelines. In the matrimonial world of power struggle, his love for Bianca cannot come into play. In order to conquer his Fortuna, he needs the virtu' of men like Petruchio. Unlike the Machiavellian Petruchio, Lucentio assumes gentility, kindness and obedience in his inferior, Bianca. He does not follow Petruchio's taming strategies as he is deceived by Bianca's gentility which, as the play reveals at the end, is a facade behind which she hides a rebellious nature. It remains for the last act to show who the better ruler is.

In Act $\mathrm{V}$, when Katherine wins the wager for Petruchio, it comes as no surprise, for she has learned how to love through fear, and submit to a higher power. A woman with no identity and no subjective vision, she is a perfect subordinate for a perfect Machiavellian ruler. Their marriage is a perfect paradigm for an orderly social system. Her final speech is a duplicate of the Elizabethan and Jacobean political theory: the ruler and the husband merge together so that they become one. She declares the final victory of the ruler over the ruled: 
Fie, Fie, unknit that threat'ning unkind brow,

And dart not scornful glances from those eyes,

To wound thy lord, thy king, thy governor.

Thy husband is thy lord, thy life, thy keeper,

Thy head, thy sovereign: one that cares for thee (5. 2. .136-138,145-146).

She defines the duties of the subordinate as to "serve, love, and obey"(5. 2. .164). And in her prostration, she enacts these duties: "In token of which duty, if he please,/My hand is ready, may it do him ease"(5. 2. 178-179).

Lucentio, however, failing to be a Machiavellian husband, becomes the butt of the joke; he has incurred the scandal of losing his patriarchal power to a woman. Bianca has shamed him when he lost the wager for Petruchio. What is more is that she denies that the wife owes obedience to her husband:

Bian. Fie, what a foolish duty call you this?

Luc. I would your duty were as foolish too.

The wisdom of your duty, fair Bianca,

Hath cost me [a] hundred crowns since supper-time.

Bian. The more fool you for laying on my duty. (5. 2. 125-129).

Lucentio longs but fails in the final test of marital authority. He has learned the lesson that order and obedience can be achieved through power not love: "'Tis a wonder, by your leave, she will be tam'd so" (5. 2. 189).Petruchio stands alone in the last scene, the center of male admiration as an ideal husband/ruler.

\section{References}

Barton, A. (1997). Introduction. The Taming of the Shrew in The Riverside Shakespeare (2nd ed.). Boston: Houghton Mifflin.

Boose, L. (1991). Scolding Brides and Bridling Scolds: Taming the Woman's Unruly Member. Shakespeare Quarterly. 42, 179-213. http://dx.doi.org/10.2307/2870547

Boose, L. (1994). The Taming of the Shrew, Good Husbandry, and Enclosure. Shakespeare Reread: The Text in New Contexts. Ithaca: Cornell UP.

Brown, C. E. (1995). Katherine of The Taming of the Shrew: 'A Second Grissel.' Texas Studies in Literature and Language, 37(3), 285-313.

Burt, R. (1984). Charisma, Coercion, and Comic Form in The Taming of the Shrew. Riticism, 26, 295-311.

Deer, H. (1991). Untyping Stereotypes: The Taming of the Shrew. The Aching Heart: Family Violence in Life and Literature. New York: Plenum Press.

Donaldson, P. S. (1988). Machiavelli and the Mystery of State. New York: Cambridge UP.

Garner, S. N. (1988). The Taming of the Shrew: Inside or Outside the Joke. In Maurice Charney (Ed.), Bad Shakespeare: Revaluations of the Shakespeare Canon (pp. 104-119). Rutherford: Farleigh Dickinson UP.

Garver, E. (1987). Machiavelli and the History of Prudence. Madison: Madison UP.

Gonzales, L. I. (2013). The Taming of the Shrew Complex and Cultural Gender Roles: The Taming of Unruly Women in Shakespeare's The Taming of the Shrew and Early Folktales (Unpublished Dissertation). Texas A\&M University, USA .

Hartwig, J. (1982). Horses and Women in The Taming of the Shrew. Huntington Library Quarterly, 45, 285-294. http://dx.doi.org/10.2307/3817090

Hutcheon, E. (2011). From Shrew to Subject: Petruchio's Humanist Education of Katherine in The Taming of the Shrew. Comparative Drama, 45(4), 315-337. http://dx.doi.org/10.1353/cdr.2011.0029

Kahn, C. (1975). The Taming of the Shrew: Shakespeare Mirror of Marriage. Modern Language Studies, 5, 88-102. http://dx.doi.org/10.2307/3194204

Moreno, V. (2010). The Taming of the Shrew: The Hostile Divide in the Feminine Soul. Psychological Perspectives, 53(1), 21-42. http://dx.doi.org/10.1080/00332920903543542

Newman, K. (1986). Renaissance Family Politics and Shakespeare's The Taming of the Shrew. English Literary Renaissance. 16, 86-100. http://dx.doi.org/10.1111/j.1475-6757.1986.tb00899.x 
Novy, M. (1979). Patriarchy and Play in The Taming of the Shrew. English Literary Renaissance, 9, 264-280. http://dx.doi.org/10.1111/j.1475-6757.1979.tb01470.x

Perret, M. (1983). Petruchio: The Model Wife. Studies in English Literature 1500- 1900, 23, 223-235. http://dx.doi.org/10.2307/450090

Quilligan, M. (1993). Staging Gender: William Shakespeare and Elizabeth Gary. Sexuality and Gender in Early Modern Europe: Institutions, Texts, Images. Cambridge: Cambridge UP.

Raab, F. (1964). The English Face of Machiavelli. London: Routledge.

Renald, M. (1987). The Manning of the Haggard or The Taming of the Shrew. Shakespeare and his Social Concept. New York: AMS Press.

Roberts, J. (1983). Horses and Hermaphrodites: Metamorphoses in The Taming of the Shrew. Shakespeare Quarterly, 34, 159-171. http://dx.doi.org/10.2307/2869831

Slights, C. (1989). The Raw and the Cooked in The Taming of the Shrew. Journal of English and German Philology, 88, 168-189.

Underdown, D. (1985). The Taming of the Scold: The Enforcement of Patriarchal Authority in Early Modern England. Order and Disorder in Early Modern England. Cambridge: Cambridge UP.

\section{Notes}

Note 1. All Machiavelli quotations are from Niccolo`Machiavelli, The Prince, trans., Peter Bondnella and Mark Musa, (Oxford: Oxford UP, 1984). The other major political tract Machiavelli wrote is The Discourses on the First Ten Books of Titus Livius, which, together with The Prince, left an indelible mark on the political discourse of early modern Europe. The discussion here draws on The Prince in detailing the characteristics of the Machiavellian character.

Note 2. For detailed accounts of the extent and level of Machiavellianism, see Felix Raab, The English Face of Machiavelli (London: Routledge, 1964), and the study by Peter S. Donaldson, Machiavelli and the Mystery of State (New York: Cambridge UP, 1988). As Donaldson has showed, there were a number of avid followers of Machiavelli in early Tudor courts - among others, William Thomas, who wrote a secret work of royal pedagogy, based on Machiavelli's works for the young prince Edward VI, and Bishop Stephen Gardiner, who wrote a Machiavellian treatise for Mary's consort, Philip of Spain.

Note 3. For a detailed discussion of the relationship between Machiavellian virtu' and prudence, see Eugene Garver, Machivelli and the History of Prudence, (Madison: Madison UP, 1987), p.31, who states that "Machiavelli 'empties' virtu' of its conventional semantic, moral, and intellectual associations in order to substitute a prudential structure for understanding it."

Note 4. It should be noted that not all feminist critics have such a bleak view on Katherine's fate. Anne Barton, for instance, contends that Petruchio's "method" has harmonized and ordered the elements of a personality without doing violence to its essential selfhood" (139). Among other self-proclaimed feminist critics, Coppelia Kahn has argued against Katherine's defeat, seeing The Shrew as a fundamentally ironic play that subverts the patriarchal conventions surrounding marriage. Likewise, Harriet Deer argues that the play undercuts its surface chauvinism by making chauvinism itself the butt of the joke (64).

Note 5. The customary punishment meted out to scolds was the ducking-stool or cucking-stool, on which the victim was seated to be ducked in a pond or a river. This mechanism for punishing women was peculiar not to medieval times but to the Elizabethan reign. See Underdown, pp120-23.

Note 6. All Shakespeare quotations are taken from G. Blakemore Evans' The Riverside Shakespeare, $2^{\text {nd }}$ ed. (Boston: Houghton Mifflin, 1997).

Note 7. Given the potentially deadly environment a prince must inhabit, Machiavelli recommends that his nature should combine two less endearing animals, the lion and the fox: "Thus, since a prince is compelled of necessity how to use the beast, he should pick the fox and the lion ... .one should need to be a fox to recognize snares and a lion to frighten wolves" (92; ch. 18).

Note 8. See also LizetteGonzales who argues that, with the awareness of folktales, the interpretation of Shakespeare's The Taming of the Shrew can be further expanded through cultural, historical and gender analysis. While the methods of "taming" unruly women change through time and culture, society will still attempt to reform women who don't act in accordance with their appropriate gender roles. 


\section{Copyrights}

Copyright for this articleis retained by the author(s), with first publication rights granted to the journal.

This is an open-access article distributed under the terms and conditions of the CreativeCommons Attribution license (http://creativecommons.org/licenses/by/3.0/). 